\title{
The Relationship between High Performance Work System and Continuance Commitment to Change: An Economic Exchange Perspective
}

\author{
Aqsa Akbar * \\ Muhammad Amir Rashid ${ }^{\dagger}$ \\ Omer Farooq $\ddagger$
}

\begin{abstract}
In response to the recently announced privatization of public sector banks of Pakistan, the current study attempts to investigate the impact of perceived high performance work systems on continuance commitment to change along with its interlinking mechanisms. A total of 1000 full-time employees were surveyed through self-administered questionnaires during August-December 2017. Out of 670 returned questionnaires, 591 completed questionnaires were analyzed. Goodness of the measures was tested by employing Confirmatory Factor Analysis. Proposed Hypotheses were tested through Structural Model in AMOS. The data largely substantiated by our theoretical framework. The findings revealed that the perceptions of economic exchange fully mediate the relation between HPWS and continuance commitment to change. Finally, theoretical and managerial implications are discussed, highlighting the issues that must be focused during chaotic nature of large-scale implementation of change initiatives in public sector.
\end{abstract}

Keywords: High performance work systems, continuance commitment to change, Public sector of Pakistan, Economic exchange perceptions.

\section{Introduction}

With the increasing demand to improve organizational efficiency, public sector around the world has been undergoing massive organizational changes to revamp its functions. Where such reforms can aid to bring positive outcomes, often overlooked areas during these reforms lies at the heart of the individuals, who are considered to be the key source of implementing changes initiatives (Bartunek, Rynes, \& Ireland, 2006; Smollan \& Sayers, 2009). Though large-scale organizational changes do requires structural and functional changes, it also requires a change in employees' mindset that can increase the chances of change success or failure (Fedor, Caldwell, \& Herold, 2006). Despite the growing importance of understanding employees' psychological responses during change, managers often fail to address this issue (B. Becker \& Gerhart, 1996). Thus, recent studies highlight the need to study employees' attitudes towards change as essential for successful implementation of change initiatives. In this regard, one of the most profound change attitude

\footnotetext{
* Department of Management Sciences, COMSATS Institute of Information Technology, Lahore Campus.

E-mail: aqsaakbar@ciitlahore.edu.pk.

${ }^{\dagger}$ Department of Management Sciences, COMSATS Institute of Information Technology, Lahore Campus.

E-mail: amirrashid@ciitlahore.edu.pk.

${ }^{\ddagger}$ College of Business and Economics, United Arab Emirates University, Al Ain, UAE. E-mail: omer@uaeu.ae.ac
} 
revealed by the change literature behind successful change implementation is commitment to change (Herscovitch \& Meyer, 2002). it is defined as "a force or a mind-set that binds an individual to a course of action deemed necessary for the successful implementation of change initiative" (Herscovitch \& Meyer, 2002). Based on theoretical foundations of the universally acknowledged model of organizational commitment (Meyer \& Allen, 1991; Meyer, Allen, \& Allen, 1997). Herscovitch and Meyer (2002) developed a threecomponent commitment to change construct. The three component model consists of Affective, normative and continuance commitment to change. Affective commitment (ACC) represents "a desire to provide support based on its inherent benefits" whereas normative commitment (NCC) to change is a sense of social obligation to support a change. Contrary to this, continuance commitment (CCC) to change recognizes the cost of withholding support for change. The concept of continuance commitment is similar to the definitions of exchange based or calculative commitment. The three different forms of commitment rest on the underlying unified approach that employees tend to stay with an organization because of several reasons which may be an emotional attachment, moral obligation or calculative. However, in comparison to affective and normative forms of commitment, the literature lacks attention towards exchange-based or continuance commitment to change. Especially, the development of more short-term and transactional form of employment relationships within organizations (Herriot \& Pemberton, 1997), highlights the need to refocus on this form of commitment. Moreover, in Asian context, continuance commitment have significance due to high collectivism, acceptance of high power distance \& lack of other alternatives (Bouckenooghe, De Clercq, \& Deprez, 2014). The current study, therefore attempts to study the management of continuance commitment to change.

Prior studies suggest the significance of high performance work system in influencing employees attitudes and behaviors. Since the primary objective of any change initiative is to manage employees attitudes towards change by fostering more readiness and less resistance, the study proposed that HPWS may add value by managing employees CCC for better implementation of change initiatives. The association between HPWS and affective commitment to change has already well-documented in the literature. Nevertheless, the impact of HPWS on continuance commitment to change has yet to be unfolded. Also, investigating the impact of HPWS on continuance commitment to change is important as continuance commitment to change either had no association or even poses negative relation with desired change outcomes (Baraldi, Kalyal, Berntson, Naswall, \& Sverke, 2010; Meyer, Srinivas, Lal, \& Topolnytsky, 2007).

Especially, this study addresses the following questions regarding "What is the relation between HPWS and continuance commitment to change?" and "What are the interlinking mechanisms that can establish a better clarity of the underlying relationship?". The study intends to answer the question through empirically testing a framework by proposing a relationship between HPWS and continuance commitment to change. This current study differs from the existing research in two ways. First, it explicitly accounts for the impact of HPWS as a contextual factor on continuance commitment to change. Second, it also accounts for the interlinking mechanism through which HPWS are related with continuance commitment to change, using social exchange theory. The study draws managers' attention to the issues that must be focused during chaotic nature of large-scale 
implementation of change initiatives in public sector.

\section{Theoretical Framework of the Study}

\section{High Performance Work System}

Based on Strategic HRM, High performance work practices (HPWPs), seems to capture the attention of current change researchers and have been identified as crucial for organizational change (Conway \& Monks, 2008; Tummers, Kruyen, Vijverberg, \& Voesenek, 2015). However, researchers acknowledge the merits of systematic approach of HPWP called as high performance work systems (HPWS)" a group of separate but interrelated HRM practices, designed to improve employees competence, attitudes \& motivation to enhance both individual and organizational performance" (Huselid, 1995; Delery, 1998; Combs, Liu, Hall, \& Ketchen, 2006; Boxall \& Macky, 2009). Where majority of the studies in literature have used HPWS to see its impact on organizational outcomes such as profitability (Wright, Gardner, Moynihan, \& Allen, 2005) and productivity (MacDuffie, 1995; Askenazy, 2001) as performance indicators, a less succinct impression begins to unfold, raising questions about connecting HPWS with employees' level variables (Kroon, Van de Voorde, \& Van Veldhoven, 2009) and financial sustainability (Raziq \& Wiesner, 2016). The mainstream perspective suggests beneficial effects of HPWS on employees level outcomes (García-Chas, Neira-Fontela, \& Varela-Neira, 2016). Contrastingly, we do find studies where HPWS has no statistically significant impact or even negative impact on employees' outcomes (Ramsay, Scholarios, \& Harley, 2000; Van De Voorde, Paauwe, \& Van Veldhoven, 2012). Based on such contrasting outcomes view about the effects of HPWS on employees level variables, recent researchers have called for more investigation to assess the impact of HPWS on employees outcomes (Takeuchi, Chen, \& Lepak, 2009; Wright et al., 2005; García-Chas et al., 2016) and specifically on the processes linking HPWS and employees' outcomes (Harley, Sargent, \& Allen, 2010; Van De Voorde \& Beijer, 2015). Focusing on the potential connection between HPWS with employee's level outcomes, further examining the effects of HPWS on change related attitudes and underlying processes might aid for better understanding the change implementation process.

\section{Continuance Commitment to Change}

Continuance commitment to change refers to the recognition of cost in case of failure to support the change initiative. This form of commitment evolves from a different driving force. Unlike affective commitment which captures how people are emotionally attached to the change, continuance commitment to change derives out of people recognition of the cost of withholding the support for change. Based on Side-bets theory (H. S. Becker, 1960) and driven from organizational continuance commitment concept, employees wish to support the change as to preserve the various accumulated side-bets. Such side-bets include personal non-transferable investments such as working relationships, acquired skills, experience and other related benefits that make it costly to leave the current organization. The becomes more obvious in case of developing countries where lack of 
other employment opportunities and financial concerns make people to think more towards the cost of withholding support for change. Moreover, continuance commitment has often found to be positively related with negative outcomes such as stress, burnout and has no or even negative association with positive outcomes such as work behaviors (Rizzuto, 2004; Cunningham, 2006). According to Romzek (1990), continuance commitment entails a transactional attachment. His view suggests that employees calculate the cost associated with leaving the organization versus the benefits associated with staying. Best (1994) argues that this form of commitment is strongest when people are available with fewer employment opportunities and when their stakes are quite high. Both of these conditions fulfill the characteristics of public sector employees in developing nations such as Pakistan. Having job security, long-term benefits, a public employees image and other benefits coupled with less employment opportunities develops a strong sense of continuance commitment. Therefore, it becomes imperative to manage such form of commitment during change initiatives.

\section{High Performance Work System and Continuance Commitment to Change}

The impact of employees' perceptions of HPWS on employees attitudes has been empirically tested in many previous researches (Macky \& Boxall, 2007; Kehoe \& Wright, 2013; Mao, Song, \& Han, 2013). One of the dominant approaches is to provide its rationale through social exchange theory (Blau, 1964) and norms of reciprocity (Gouldner, 1960). According to this, social exchange relationships formed through the way organizations' treat its employees (Gould-Williams \& Davies, 2005). It suggests when individuals are involved in rewarding relationships, they become bound to return favors to exchange partner (Blau, 1964). Similarly, when HPWS are implemented effectively, it causes employees to perceive their relationship with organization as supportive and meaningful. In other words, when employees perceive human resource practices as a sign of appreciation, they reciprocate through favorable attitudes such as increased commitment (Hornung, Rousseau, \& Glaser, 2008) and vice versa.

As earlier mentioned, continuance commitment to change develop when employees perceives that it's costly not to support the change (Herscovitch \& Meyer, 2002). This happens when an organization fails to develop a socioemotional relationship with employees through its practices such as HPWS. Connecting the same line, when employees perceive HPWS as not supportive, it would not be able to create any emotional or moral bound with the organization, rather just an expensive option not to support the change otherwise. Based on above discussion, we argue that change managers can reduce continuance commitment to change through effective HPWS. Expecting a negative relationship, we hypothesize

Hypothesis 1: A negative relationship exists between employees perception of HPWS and continuance commitment to change. 


\section{Mediating Impact of Perceptions of Economic Exchange}

Most of the previous researches investigated the direct impact of HPWP on commitment to change (Conway \& Monks, 2008; Fugate, 2012, 2012; Tummers et al., 2015), yet the interlinking mechanisms received less attention. Few studies have focused on the micromechanisms of black box linking HPWS and employees outcomes from the employees' perspective (Takeuchi et al., 2009; Mao et al., 2013). Though many mediating factors have been found to influence the perceived HPWS and employees attitude relationship such as the role of employees climate between HPWS and job satisfaction (Takeuchi et al., 2009), the mediating role of behavioural script, skill variety, and autonomy between HPWS and job satisfaction and affective commitment (Mao et al., 2013), the results are quite mixed as more mediating variables can possibly influence this relationship. This offers the opportunity to unearth the processes through more mediating variables between employees level HPWS and employees attitudes (Mao et al., 2013). We also aim to fill this gap by exploring the mechanisms that link the employees level HPWS and employees attitudes with the help of social exchange theory (Blau, 1964).

In addition to general reciprocation as embedded in social exchange theory, the theory can explain why individuals express favorable attitudinal \& behavioral returns to organizations (Settoon, Bennett, \& Liden, 1996). A central tenet of this theory revolves around the idea that employees develop such exchanges for two basic reasons (i.e. socioemotional and economic reasons) \& that the perceptions of the nature of such exchanges in employee-employer relationships can predict employee side attitudes \& behaviors with regard to the employer (Kuvaas \& Dysvik, 2009). Both HR and commitment literature have emphasized on significance of social \& economic exchanges as explanatory mechanisms for linking them with other variables (Shore, Tetrick, Lynch, \& Barksdale, 2006; Kuvaas \& Dysvik, 2009), but received less attention in explicitly measuring employee perceptions of social \& economic exchanges independently in employee-employer relationship (Coyle-Shapiro \& Conway, 2004). Literature found that organizational actions or practices proved to be significant antecedents of nature of the social and economic exchanges (Kuvaas \& Dysvik, 2009). Thus we propose that employees perceptions of exchanges may mediate the relationship between perceived HPWS and commitment to change.

Shore et al. (2006) developed a model of exchange separating economic \& social exchanges by focusing on the nature of the exchange relationship between employer and employee, from an employee perspective. The difference of economic \& social exchange rests on four dimensions 1 . The degree of trust; 2. Duration (long-term i.e. social exchange vs. short term i.e. economic exchange) (Blau, 1964), 3. Level of investment in the relationship 4. Financial or socioemotional. Based on the above differentiation, we hypothesize that when employees 'score low on HPWS, it may reflect little investment, a more materialistic social climate, transactional and short-term orientation towards employees well-being, and discrete economic agreement, that lead to build perceptions of economic exchanges, which in turn expect to affect continuance commitment, that revolves around the cost of withholding the support for change. Thus, we hypothesize that: 
Hypothesis 2: Employees' perceptions of economic exchanges mediate the relationship between perceived HPWS and continuance commitment to change.

\section{The Conceptual Framework of the Study}

Figure 1

Theoretical Model

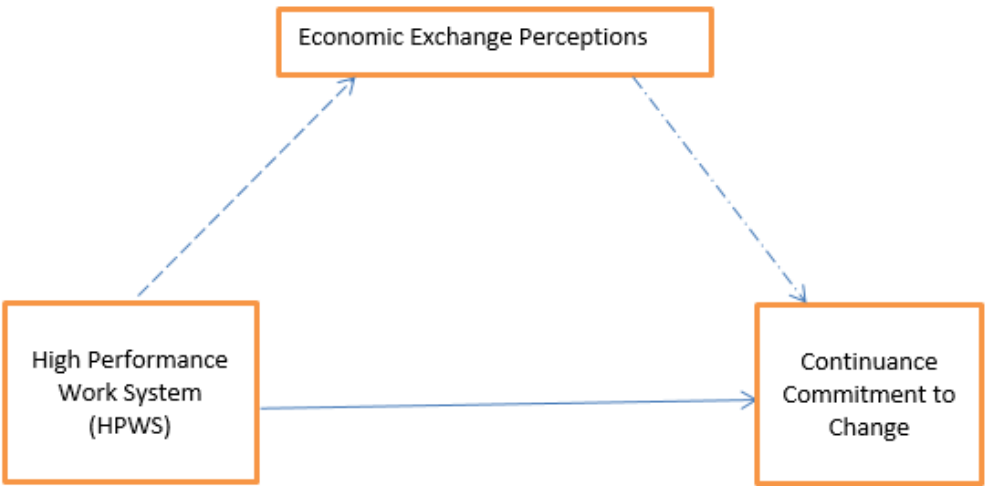

Represents the hypothesized relationships

Represents the Mediation

\section{Research Methodology}

\section{Sample and Procedure}

To test the proposed theoretical framework, data is collected through a survey from the employees of the largest state-owned bank of Pakistan, recently announced for privatization. Employees from the Punjab region of the bank filled self-administered questionnaires. In this regard, we contacted the regional head office to get the permission and administrative support. To ensure the confidentiality of employees, we did not include the information regarding names and locations. Around 1000 questionnaires were sent to regional head offices during August-December 2017. Due to top management's endorsement, we could be able to receive 650 filled questionnaires (73\% return rate). After carefully scrutinizing the questionnaire by deleting all missing data cases, a usable sample of 591 was selected for final analysis.

\section{Survey Instrument}

All the survey items were measured on a five-point Likert scale ranging from strongly disagree (1) to Strongly Agree (5). The first section of the questionnaire consists of de- 
mographic variables. All the variables used in the present study has already established measures.

\section{Measures}

\section{Continuance Commitment to Change}

Continuance commitment to change is measured through 6-items adapted from Herscovitch and Meyer (2002) commitment to change scale. A sample item for measuring normative commitment to change includes "I have no choice but to go along with the Privatization program". The reliability of this scale for the current study is (Cronbach alpha=0.91).

\section{Economic Exchange}

Measure for social exchange is used by 6 items developed by Shore et al. (2006), All the items are measured on a 5 point Likert scale ranging from strongly disagree to strongly agree. Sample items include "My relationship with my organization is strictly an economic one, I work and they pay me". The reliability of this construct is (Cronbach al$\mathrm{pha}=0.83)$.

\section{Perceived HPWS}

28 item scale of HPWS is selected from the work of Siddique (2014) framework that were used in the state-owned bank to measure the employee's perceptions of HPWS. As widely recommended in the literature, an additive approach has been used to aggregate the unitary index of HPWS (Huselid, 1995; Chuang \& Liao, 2010; Pak \& Kim, 2016; Ostroff \& Bowen, 2000; Liao, Toya, Lepak, \& Hong, 2009). This approach is based on a fundamental assumption of strategic human resource management that system approach of HPWS is better than testing the impact of individual HR practices (Lepak, Liao, Chung, \& Harden, 2006). The Practices include job/ employment security, employees' participation, training, information sharing, job clarity/ JD as role clarity, compensation, performance appraisals. These practices besides being universal in nature also have relevance to change management literature and have well-validated measures as well. Sample items include "My job is secure as long as I perform well", "My job has an up to date job description". The Cronbach alpha of HPWS is 0.93 .

\section{Results}

\section{Respondents Descriptive}

Respondents 'age distribution suggests that majority of the respondents are middle-aged employees. A total of $39.1 \%$ respondents belong to age group between 31-40. The next age group lies between $40-50$ is $34.5 \%$. As compared to this, less percentage of respondents belong to age group between $20-30$ which is $15.7 \%$ and age group above 50 which 
is just $10.7 \%$. The respondents' level of qualification shows that majority of the respondents are highly qualified with $60.7 \%$ lies in Postgraduate qualification domain. $29.9 \%$ are graduate and only $10 \%$ are undergraduate. Such qualification distribution shows that this bank prefers highly qualified professionals. As far as respondents' experience is concerned, the largest percentage of respondents of the current study have more than 15 years of experience in the banking sector with $34.5 \%$ lies in above 15 years of experience domain. $26.9 \%$ respondents belong to the experience domain of $5-10$ years and $23.9 \%$ lies in 11-15 years of experience domain. The smallest percentage of respondents i.e. $14.7 \%$ have less than 5 years of experience. Such heavy distribution of respondents' experience towards more than 10 years shows that the bank emphasis on HR practices such as job security. Gender distribution of respondents' shows the dominance of males with $75.6 \%$ as compared to females which comprise of only $24.4 \%$. There are several reasons that account for male dominance in Pakistani workplaces especially in banking sector such as social and cultural issues.

\section{Reliabilities and Validities}

Table 1 presents the means, intercorrelations, standard deviations, Cronbach alpha, convergent and discriminant validity of all variables.The appropriateness of this study measurement model is assessed by first performing a confirmatory factor analysis (CFA) using the Analysis of moment structures (AMOS 21) (Arbuckle, 1997). The 5-factor model showed a good model fit with $X^{2}=5260.891 \mathrm{p}<.000 \mathrm{df}=1204 ; X^{2} / \mathrm{df}=4.3$; Root mean square error of approximation $($ RMSEA $)=0.7$; Tucker-Lewis index $(\mathrm{TLI})=0.77$; Normed fit index $(\mathrm{NFI})=0.74$ and comparative fit index $(\mathrm{CFI})$ of 0.78 .

Table 1

Means, Standard Deviations, intercorrelation, Average Variance Extracted, Reliabilities and Discriminant Validity test for all Variables

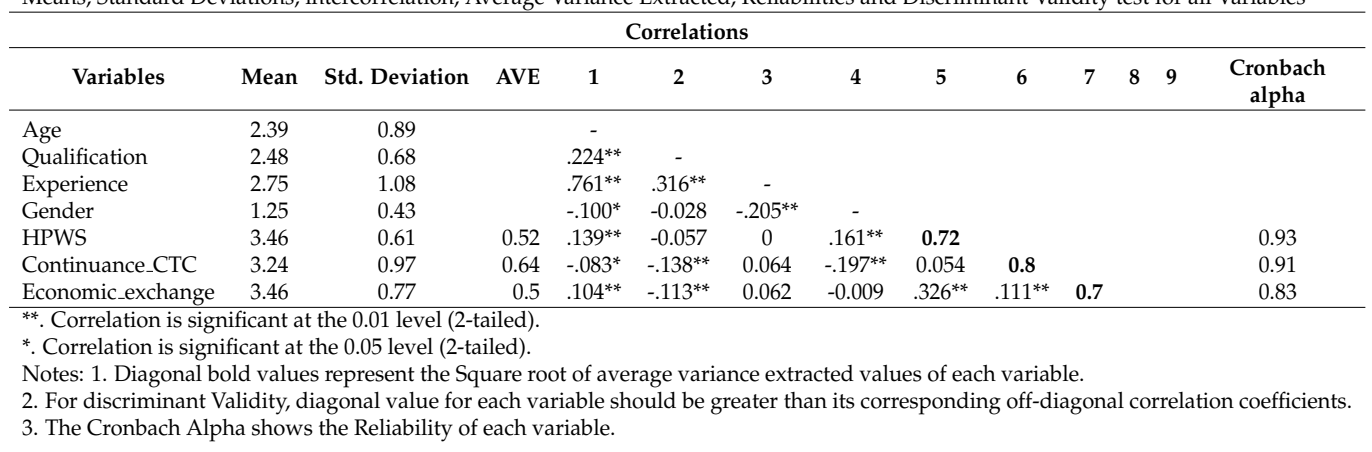

\section{Estimation of Model}

\section{Standardized and Unstandardized Estimates}

In order to test the path analysis, AMOS presents standardized and unstandardized model solutions. In AMOS, the default way of parameter estimates with desirable properties is 
computed through Maximum likelihood (Arbuckle, 1997). In unstandardized model solution, AMOS shows regressions weights, variances, and co-variances. According to Byrne (2016), regression weights indicates the impact of one variable over another. On the other hand, standardized regressions model presents standardized regression weights, squared multiple correlations and correlations.

\section{Testing the Direct Effects}

After the fit indices, results show the testing of hypothesized relationship. The hypothesis of the current study are :

Hypothesis: A negative association exists between employees' perception of HPWS and continuance commitment to change. Table 2 shows the coefficient of the hypothesized regression path and its significance.

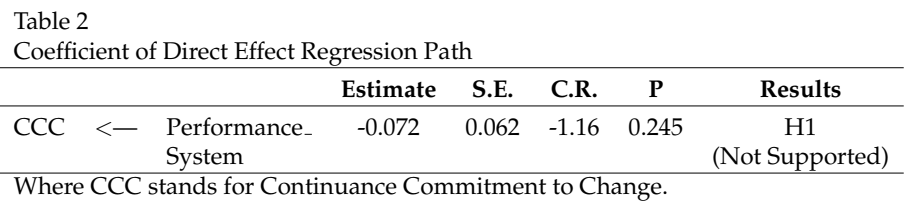

\section{Test of Mediation}

The mediation hypothesis was tested through SEM by first controlling the effects of age, gender, qualification, and experience. After that, direct, indirect and mediations effects were tested without including our proposed moderating variables. According to Iacobucci, Saldanha, and Deng (2007), direct and indirect paths must be simultaneously specified to estimate either effect. Moreover, all the insignificant paths must also be removed from the model. The hypothesized effect along with the direct effect of HPWS on continuance commitment to change has been incorporated to specify the model. As the direct effect of HPWS on Continuance commitment to change was insignificant, this path was removed in the model (Iacobucci et al., 2007; Kline, 2011; Farooq, Rupp, \& Farooq, 2017). Though not much improved, fit indices showed model fit with $\mathrm{X} 2=3282.571 \mathrm{p}<.000 ; \mathrm{df}=690$ $X^{2} / \mathrm{df}=4.7$; Root mean square error of approximation (RMSEA) $=0.075$; Tucker-Lewis in$\operatorname{dex}(\mathrm{TLI})=0.8$; Normed fit index $(\mathrm{NFI})=0.7$ and comparative fit index $(\mathrm{CFI})$ of 0.8 . Result showed the negative impact of HPWS on continuance commitment to change via a mediating impact of economic exchange perceptions (Table 3). In other words, the negative impact of HPWS on continuance commitment to change is mediated via the perceptions of economic exchange. As one indirect path was found to be significant, perceptions of economic exchange fully mediate the HPWS and continuance commitment to change the relationship (H2 Supported). 
Table 3

Direct and Indirect effects (via Economic Exchange ) of HPWS on Continuance CTC

\begin{tabular}{|c|c|c|c|c|c|}
\hline \multirow[b]{2}{*}{ Factors } & \multirow{2}{*}{$\begin{array}{c}\text { Economic Exchange } \\
\text { Direct }\end{array}$} & \multicolumn{4}{|c|}{ Continuance Commitment to Change } \\
\hline & & Direct Effect & Indirect Effect & Total Effect & Type of Mediation \\
\hline HPWS & $-0.341^{* * *}$ & NS & $.048^{*}$ & 0.048 & Full Mediation \\
\hline
\end{tabular}

\section{Discussion}

Increasing prevalence of change in today's organizations is becoming theoretically and pragmatically imperative for better survival (Gordon, Stewart Jr, Sweo, \& Luker, 2000; De Meuse, Marks, \& Dai, 2011). However, smooth implementation of such changes presents a challenging domain. For this, change researchers emphasize the role of employees' commitment to change as crucial, yet difficult to be managed during organizational change initiatives? Given the potential connection of HPWS and employees change reactions, the purpose of this study was to explore the role of organizational contextual factors that may help to manage employees' continuance commitment to change, along with its interlinking mechanism. With respect to the first hypothesis, though results show a negative relation between HPWS and continuance commitment to change, it fails to show a statistically significant relationship $(\beta=-0.072, \mathrm{p}>0.05)$. Thus, the result could not substantiate H1. The mediating mechanism proposed in this study might be the possible reason behind it. In this article, we proposed that the nature of exchange (i.e., economic exchange) may mediate the relationship between HPWS and continuance commitment to change, thus recognizing the relatively independent aspect of exchanges in an employeremployee relationship (Hypothesis 2). The mediating result of this hypothesis has shown a full mediation, i.e. no significant direct relation between HPWS and CCC, rather HPWS impacts CCC through perceptions of economic exchange. Both HPWS and CCC literature has found a significant association with economic exchange. Based on the distinction between social and economic exchange given by shore et al., (2006), HPWS comprising of lack of trust and impersonal, short-term oriented while investing in employees, and of more financial nature, leads to perceptions of economic exchange, which in turn is associated with less positive outcomes. Similarly, in commitment literature, CCC develops when employees recognize the cost of benefits, which they lose in case of withholding the support (side-bets theory). This suggests that employees will be bound to stay with the organization, not because of emotional attachment or moral obligation, rather just a costly option to lose. Becker (1960) cited economic investments such as compensation, pension plans are likely to develop this form of commitment. In other words, low perceptions of HPWS will make people believe that relationship between organization and them is an economic one, thus creating an economic exchange. This, in turn, will not be able to connect employees with the employer, rather just a concrete economic relationship, leading to develop continuance commitment. The case becomes more intense in developing nations where lack of employment opportunities make economic concerns, a prior issue (Bouckenooghe et al., 2014). It also highlights the significance of contextual effects of labor 
markets while understanding exchange relationships. Moreover, since HPWS is assumed to create social exchanges, throwing a light on the economic aspect of HPWS might be able to explain the links where it negatively influences the employees' outcomes.

\section{Practical Implications}

The current study has significant implications for change implementers. Although other environmental factors are likely to influence change initiative success, committed employees form a groundwork to ensure smooth change implementation. Change managers should direct their attention towards the nature of exchange dynamics while implementing HPWS, whose impact on employees attitudes have been widely attested in the literature (Liao et al., 2009; Mao et al., 2013). Moreover, change initiatives that tend to attract high resistance, economic exchanges may be encouraged for a short term to ensure minimum reciprocation through continuance commitment. Understanding the key determinants of employees positive attitudes towards change with respect to exchange dynamics can assist the managers in the pro-active planning of change process for maximizing the probability of successful change interventions.

\section{Direction for Future Research}

This study might open an avenue for future researchers to distinguish HPWS practices into two categories based on the type of exchange they establish, suggesting the existence of different HPWS, which could lead to different employees' outcomes. Moreover, assessing the impact of HPWS on employees' outcomes from only employees' perspective might not be sufficient enough to depict the objective measures of the context (i.e. HPWS). Both perceptual and objective measures of the context are required to examine the influence of HPWS on employees' outcomes (Boxall \& Macky, 2009). According to Social information processing view (Salancik \& Pfeffer, 1978), HPWS implemented by managers provides a contextual cue in which employees perceptions are formed, thus suggesting future researchers to focus on a cross level-relationships while studying HPWS-employees relationship. 


\section{References}

Arbuckle, J. L. (1997). Amos user's guide version 3.6. Chicago. SmallWaters Corporation.

Askenazy, P. (2001). Innovative workplace practices and occupational injuries and illnesses in the United States. Economic and Industrial Democracy, 22(4), 485-516.

Baraldi, S., Kalyal, H. J., Berntson, E., Naswall, K., \& Sverke, M. (2010). The importance of commitment to change in public reform: An example from Pakistan. Journal of Change Management, 10(4), 347-368.

Bartunek, J. M., Rynes, S. L., \& Ireland, R. D. (2006). What makes management research interesting, and why does it matter? Academy of Management Journal, 49(1), 9-15.

Becker, B., \& Gerhart, B. (1996). The impact of human resource management on organizational performance: Progress and prospects. Academy of Management Journal, 39(4), 779-801.

Becker, H. S. (1960). Notes on the concept of commitment. American Journal of Sociology, 66(1), 32-40.

Best, P. W. (1994). Locus of control, personal commitment and commitment to the organization. Unpublished MCom thesis, University of South Africa, Pretoria.

Blau, P. (1964). Exchange and power in social life. New York: Wiley.

Bouckenooghe, D., De Clercq, D., \& Deprez, J. (2014). Interpersonal justice, relational conflict, and commitment to change: The moderating role of social interaction. Applied Psychology, 63(3), 509-540.

Boxall, P., \& Macky, K. (2009). Research and theory on high-performance work systems: progressing the high-involvement stream. Human Resource Management Journal, 19(1), 3-23.

Byrne, B. M. (2016). Structural equation modeling with amos: Basic concepts, applications, and programming. Routledge.

Chuang, C.-H., \& Liao, H. (2010). Strategic human resource management in service context: Taking care of business by taking care of employees and customers. Personnel Psychology, 63(1), 153-196.

Combs, J., Liu, Y., Hall, A., \& Ketchen, D. (2006). How much do high-performance work practices matter? A meta-analysis of their effects on organizational performance. Personnel Psychology, 59(3), 501-528.

Conway, E., \& Monks, K. (2008). HR practices and commitment to change: An employeelevel analysis. Human Resource Management Journal, 18(1), 72-89.

Coyle-Shapiro, J. A., \& Conway, N. (2004). The employment relationship through the lens of social exchange. Oxford University Press, Oxford, UK.

Cunningham, G. B. (2006). The relationships among commitment to change, coping with change, and turnover intentions. European Journal of Work and Organizational Psychology, 15(1), 29-45.

Delery, J. E. (1998). Issues of fit in strategic human resource management: Implications for research. Human Resource Management Review, 8(3), 289-309.

De Meuse, K., Marks, M., \& Dai, G. (2011). Organizational downsizing, mergers and acquisitions, and strategic alliances: Using theory and research to enhance practice. APA Handbook of Industrial and Organizational Psychology, 3, 729-768. 
Farooq, O., Rupp, D. E., \& Farooq, M. (2017). The multiple pathways through which internal and external corporate social responsibility influence organizational identification and multifoci outcomes: The moderating role of cultural and social orientations. Academy of Management Journal, 60(3), 954-985.

Fedor, D. B., Caldwell, S., \& Herold, D. M. (2006). The effects of organizational changes on employee commitment: A multilevel investigation. Personnel Psychology, 59(1), $1-29$.

Fugate, M. (2012). The impact of leadership, management, and HRM on employee reactions to organizational change. Emerald Group Publishing Limited.

García-Chas, R., Neira-Fontela, E., \& Varela-Neira, C. (2016). High-performance work systems and job satisfaction: A multilevel model. Journal of Managerial Psychology, 31(2), 451-466.

Gordon, S. S., Stewart Jr, W. H., Sweo, R., \& Luker, W. A. (2000). Convergence versus strategic reorientation: The antecedents of fast-paced organizational change. Journal of Management, 26(5), 911-945.

Gouldner, A. W. (1960). The norm of reciprocity: A preliminary statement. American Sociological Review, 161-178.

Gould-Williams, J., \& Davies, F. (2005). Using social exchange theory to predict the effects of HRM practice on employee outcomes: An analysis of public sector workers. Public Management Review, 7(1), 1-24.

Harley, B., Sargent, L., \& Allen, B. (2010). Employee responses to 'high performance work system' practices: An empirical test of the disciplined worker thesis. Work, Employment and Society, 24(4), 740-760.

Herriot, P., \& Pemberton, C. (1997). Facilitating new deals. Human Resource Management Journal, 7(1), 45-56.

Herscovitch, L., \& Meyer, J. P. (2002). Commitment to organizational change: Extension of a three-component model. Journal of Applied Psychology, 87(3), 474-487.

Hornung, S., Rousseau, D. M., \& Glaser, J. (2008). Creating flexible work arrangements through idiosyncratic deals. Journal of Applied Psychology, 93(3), 655-664.

Huselid, M. A. (1995). The impact of human resource management practices on turnover, productivity, and corporate financial performance. Academy of Management Journal, 38(3), 635-672.

Iacobucci, D., Saldanha, N., \& Deng, X. (2007). A meditation on mediation: Evidence that structural equations models perform better than regressions. Journal of Consumer Psychology, 17(2), 139-153.

Kehoe, R. R., \& Wright, P. M. (2013). The impact of high-performance human resource practices on employees' attitudes and behaviors. Journal of Management, 39(2), 366391.

Kline, R. B. (2011). Convergence of structural equation modeling and multilevel modeling.

Kroon, B., Van de Voorde, K., \& Van Veldhoven, M. (2009). Cross-level effects of highperformance work practices on burnout: Two counteracting mediating mechanisms compared. Personnel Review, 38(5), 509-525.

Kuvaas, B., \& Dysvik, A. (2009). Perceived investment in permanent employee development and social and economic exchange perceptions among temporary employees. 
Journal of Applied Social Psychology, 39(10), 2499-2524.

Lepak, D. P., Liao, H., Chung, Y., \& Harden, E. E. (2006). A conceptual review of human resource management systems in strategic human resource management research. Emerald Group Publishing Limited.

Liao, H., Toya, K., Lepak, D. P., \& Hong, Y. (2009). Do they see eye to eye? Management and employee perspectives of high-performance work systems and influence processes on service quality. Journal of Applied Psychology, 94(2), 371-391.

MacDuffie, J. P. (1995). Human resource bundles and manufacturing performance: Organizational logic and flexible production systems in the world auto industry. ILR Review, 48(2), 197-221.

Macky, K., \& Boxall, P. (2007). The relationship between ‘high-performance work practices' and employee attitudes: an investigation of additive and interaction effects. The International Journal of Human Resource Management, 18(4), 537-567.

Mao, N., Song, H., \& Han, Y. (2013). High-performance work systems and influence processes on employees' attitudes: Perspectives from China. International Journal of Manpower, 34(7), 736-752.

Meyer, J. P., \& Allen, N. J. (1991). A three-component conceptualization of organizational commitment. Human Resource Management Review, 1(1), 61-89.

Meyer, J. P., Allen, N. J., \& Allen, N. J. (1997). Commitment in the workplace. Sage Publications.

Meyer, J. P., Srinivas, E., Lal, J. B., \& Topolnytsky, L. (2007). Employee commitment and support for an organizational change: Test of the three-component model in two cultures. Journal of Occupational and Organizational Psychology, 80(2), 185-211.

Ostroff, C., \& Bowen, D. E. (2000). Moving hr to a higher level: HR practices and organizational effectiveness. San Francisco, CA: Jossey-Bass.

Pak, J., \& Kim, S. (2016). Team manager's implementation, high performance work systems intensity, and performance: A multilevel investigation. Journal of Management. doi: $10.1177 / 0149206316646829$

Ramsay, H., Scholarios, D., \& Harley, B. (2000). Employees and high-performance work systems: Testing inside the black box. British Journal of Industrial Relations, 38(4), 501-531.

Raziq, A., \& Wiesner, R. (2016). High performance management practices and sustainability of SMEs. evidence from manufacturing and services-based industries in pakistan. Journal of Management Sciences, 3(2), 83-107.

Rizzuto, T. E. (2004). Multi-level acceptance and commitment to technology change in governmental agencies (Unpublished doctoral dissertation).

Romzek, B. S. (1990). Employee investment and commitment: The ties that bind. Public Administration Review, 50(3), 501-531.

Salancik, G. R., \& Pfeffer, J. (1978). A social information processing approach to job attitudes and task design. Administrative Science Quarterly, 23(2), 224-253.

Settoon, R. P., Bennett, N., \& Liden, R. C. (1996). Social exchange in organizations: Perceived organizational support, leader-member exchange, and employee reciprocity. Journal of Applied Psychology, 81(3), 219-227. 
Shore, L. M., Tetrick, L. E., Lynch, P., \& Barksdale, K. (2006). Social and economic exchange: Construct development and validation. Journal of Applied Social Psychology, $36(4), 837-867$.

Siddique, M. (2014). Exploring the linkages between high performance work systems and organizational performance: The role of relational coordination in the banking sector of Pakistan (Unpublished doctoral dissertation). University of Newcastle Upon Tyne.

Smollan, R. K., \& Sayers, J. G. (2009). Organizational culture, change and emotions: A qualitative study. Journal of Change Management, 9(4), 435-457.

Takeuchi, R., Chen, G., \& Lepak, D. P. (2009). Through the looking glass of a social system: cross-level effects of high-performance work systems on employees' attitudes. Personnel Psychology, 62(1), 1-29.

Tummers, L., Kruyen, P. M., Vijverberg, D. M., \& Voesenek, T. J. (2015). Connecting hrm and change management: The importance of proactivity and vitality. Journal of Organizational Change Management, 28(4), 627-640.

Van De Voorde, K., \& Beijer, S. (2015). The role of employee HR attributions in the relationship between high-performance work systems and employee outcomes. Human Resource Management Journal, 25(1), 62-78.

Van De Voorde, K., Paauwe, J., \& Van Veldhoven, M. (2012). Employee well-being and the HRM-organizational performance relationship: A review of quantitative studies. International Journal of Management Reviews, 14(4), 391-407.

Wright, P. M., Gardner, T. M., Moynihan, L. M., \& Allen, M. R. (2005). The relationship between HR practices and firm performance: Examining causal order. Personnel Psychology, 58(2), 409-446. 